\title{
A Review of Practical Issues on the Use of Glucagon- Like Peptide-1 Receptor Agonists for the Management of Type 2 Diabetes
}

\author{
Irene Romera • Ana Cebrián-Cuenca · Fernando Álvarez-Guisasola • \\ Fernando Gomez-Peralta · Jesús Reviriego
}

Received: July 30, 2018 / Published online: November 30, 2018

(C) The Author(s) 2018

\begin{abstract}
Glucagon-like peptide-1 receptor agonists (GLP-1 RAs) are well established as effective treatments for patients with type 2 diabetes. GLP-1 RAs augment insulin secretion and suppress glucagon release via the stimulation of GLP-1 receptors. Although all GLP-1 RAs share the same underlying mechanism of action, they differ in terms of formulations, administration, injection devices and dosages. With six GLP-1 RAs currently available in Europe (namely, immediate-release exenatide, lixisenatide, liraglutide; prolonged-release exenatide, dulaglutide and semaglutide), each with its own characteristics and administration requirements, physicians caring for patients in their routine practice face
\end{abstract}

Enhanced Digital Features To view enhanced digital features for this article go to https://doi.org/10.6084/ m9.figshare.7308866.

I. Romera $(\bowtie) \cdot$ J. Reviriego

Eli Lilly and Company, Madrid, Spain

e-mail: romera_irene@lilly.com

A. Cebrián-Cuenca

Centro de Salud San Antón, Cartagena, Spain

F. Álvarez-Guisasola

Centro de Salud Ribera del Órbigo, Benavides de

Órbigo, León, Spain

F. Gomez-Peralta

Unidad de Endocrinología y Nutrición, Hospital

General de Segovia, Segovia, Spain the challenge of being cognizant of all this information so they are able to select the agent that is most suitable for their patient and use it in an efficient and optimal way. The objective of this review is to bring together practical information on the use of these GLP-1 RAs that reflects their approved use.

Funding: Eli Lilly and Company.

Plain Language Summary: Plain language summary available for this article.

Keywords: Administration; Clinical practice; Devices; Diabetes; European Prescribing Information; GLP-1 RAs; Warnings

\section{PLAIN LANGUAGE SUMMARY}

Type 2 diabetes (T2D) is a common condition characterized by insulin resistance and dysfunction of insulin-producing beta cells. T2D can be treated using glucagon-like peptide-1 receptor agonists (GLP-1 RAs). These wellestablished and effective treatments lower blood sugar levels and reduce body weight. Six GLP-1 RAs are currently available in Europe: the immediate-release formulations exenatide, lixisenatide and liraglutide and the prolongedrelease formulations exenatide, dulaglutide and semaglutide. These drugs all have the same mechanism of action, but they differ in a number of important features, including (1) 
treatment frequency (e.g. twice daily vs. once weekly); (2) whether they need to be taken at a particular time in relation to meals; (3) suitability for use in particular patient populations (e.g. elderly patients and those with kidney or liver problems); and (4) characteristics of the injection device (e.g. whether it is 'ready to use' by the patient or requires mixing of different components, and whether the needle is preattached and hidden or needs to be attached by the patient). The GLP-1 RAs also show some differences in their effects on cardiovascular events and in the incidence of side effects such as nausea and vomiting. First opinion physicians need to be aware of all this information so that they can select the agent that is most suitable for each patient. The aim of this review is to bring together practical information on the use of the GLP-1 RAs.

\section{INTRODUCTION}

The first step in the management of type 2 diabetes (T2D) is modification of diet and lifestyle, often with the addition of the oral antidiabetic drug metformin, which nowadays is the drug of first choice for monotherapy. As the disease progresses, treatment of T2D becomes more complex. When initial approaches are no longer sufficient to maintain the glycated hemoglobin (HbA1c) target, even with the highest approved dosage of metformin, guidelines recommend that additional antidiabetic drugs be added to the treatment regimen [1]. Comorbidities further complicate the management of T2D, as they need to be taken into account when considering the most appropriate drug and doses if treatment intensification is needed. Indeed, in studies conducted both in Europe and the USA, over $90 \%$ of patients with T2D exhibited two or more chronic conditions, the most common being hypertension, overweight/obesity, hyperlipidemia, chronic kidney disease and/or cardiovascular (CV) disease [2]. Thus, although glucose control remains the major focus in the management of patients with T2D, treatment should always be considered in the context of a comprehensive approach to include comorbid conditions [1].
In addition to metformin, available glucoselowering agents include sulfonylureas, thiazolidinediones, glinides, alpha-glucosidase inhibitors, dipeptidyl peptidase-4 (DPP4) inhibitors, sodium-glucose cotransporter 2 (SGLT2) inhibitors, GLP-1 RAs and insulin.

Drugs belonging in the GLP-1 RA class, the focus of this review, reduce glucose levels by augmenting insulin secretion and suppressing glucagon release in a glucose-dependent manner; GLP-1 RAs also delay gastric emptying and increase satiety [3]. GLP-1 RAs reduce fasting and postprandial glucose levels by stimulating GLP-1 receptors [4]. The physiological effects of GLP-1 RAs are summarized in Table 1 [5-9]. Endogenous GLP-1 has a half-life of 2-3 min due to degradation by DPP-4. In contrast, GLP-1 RAs are resistant to degradation by DPP-4, resulting in prolongation of their half-life and facilitating their clinical use [3].

GLP-1 RAs have been available in Europe and the USA for more than a decade. The first available GLP-1 RA, immediate-release, twicedaily exenatide, was approved in Europe in 2006. Additional agents subsequently gained regulatory approval and are currently being marketed, including once-daily lixisenatide and liraglutide, and once-weekly prolonged-release exenatide, dulaglutide and semaglutide. Albiglutide, another once-weekly GLP-1 RA, is not included in this review as its manufacture and sale were discontinued in July 2018 [10].

GLP-1 RAs share the same underlying mechanism of action, but they differ in terms of formulations, administration, injection devices and dosages. Although all of the known GLP-1 RAs produce clinically significant reductions in HbA1c levels and body weight, some differences between them have been reported in head-tohead studies [11], including their impact on CV risk factors [12] and gastrointestinal tolerability [13].

With six GLP-1 RAs currently available in Europe, each with its own characteristics and administration requirements, physicians caring for patients in their routine practice face the challenge of being cognizant of all this information in order to be able to select the agent most suitable for their patient and use it in an efficient and optimal way. In fact, some surveys 
Table 1 The physiological effects of glucagon-like peptide-1 receptor agonists

\begin{tabular}{lll}
\hline Location & Increased & Decreased \\
\hline Brain & Neuroprotection (preclinical) & Appetite \\
Cardiovascular system & Regional and global LV function & Blood pressure \\
& Heart rate (Clinical) & Endothelial dysfunction (Preclinical) \\
& - & Ischemia-induced myocardial damage \\
Muscle & Glucose uptake & - \\
Adipose tissue & Glucose uptake & - \\
& Lipolysis & - \\
Liver & - & Glucose production \\
& & Lipid profile \\
Stomach & - & Gastric emptying (Clinical) \\
Kidney & Natriuresis & - \\
Pancreas & Glucose-dependent insulin secretion (Clinical) & Glucose-dependent glucagon secretion $($ Clinical) \\
& Beta cell proliferation & Beta cell apoptosis \\
\hline
\end{tabular}

Data were extracted from references [5-9]

$L V$ left ventricular

${ }^{a}$ Indirect action

${ }^{b}$ In animal models

indicate that there is a need for more education and knowledge on the use of these agents in primary care settings [14]. The objective of this review is to bring together practical information based on European Union (EU) labeling on the use of available GLP-1 RAs, focusing on posology, modes of administration/devices, clinical efficacy, use in special populations and safety and precautions. In this review we focus on EU labels; as such, an in-depth review of available clinical data on these GLP-1 RAs is beyond the scope of the article. Therefore, information from observational or pragmatic studies or information from prescribing information approved in other regions is not included, with the exception of certain safety information. This article is based on previously conducted studies and does not contain any studies with human participants or animals performed by any of the authors. The aim of the paper is to gather very practical information to facilitate the use of this class of drugs.

\section{POSOLOGY AND MODE OF ADMINISTRATION}

Initial recommended dosages and administration requirements with regard to meals for each of the GLP-1 RAs discussed in this review are presented in Table 2. Of note, GLP-1 RAs administered daily require dose titration, whereas this is not necessary for the onceweekly drugs dulaglutide and exenatide. The recommended dose of dulaglutide when used in combination with other glucose-lowering agents, including insulin, is $1.5 \mathrm{mg}$ once weekly; when used as monotherapy, the recommended dose of dulaglutide is $0.75 \mathrm{mg}$ once weekly [15]. The recommended dose of prolonged-release exenatide is $2 \mathrm{mg}$ once weekly [16]. The starting dose of once-weekly semaglutide is $0.25 \mathrm{mg}$; this should be increased to $0.5 \mathrm{mg}$ after 4 weeks and can be further increased to $1 \mathrm{mg}$ if required after at least 4 weeks at $0.5 \mathrm{mg}$ once weekly [17]. 
Table 2 Dosage and administration requirements for glucagon-like peptide-1 receptor agonists based on European Union summary of product characteristics of each agent

\begin{tabular}{|c|c|c|c|c|c|}
\hline Drug & Titration & $\begin{array}{l}\text { Initial } \\
\text { dosage }\end{array}$ & $\begin{array}{l}\text { Recommended } \\
\text { dosage }\end{array}$ & $\begin{array}{l}\text { Administration in } \\
\text { relation to meals }\end{array}$ & Missed dose \\
\hline \multicolumn{6}{|l|}{ Once-daily } \\
\hline Exenatide & Yes & $\begin{array}{l}5 \text { mcg BID } \\
\text { for at } \\
\text { least } \\
1 \text { month }\end{array}$ & $5-10 \mathrm{mcg} \mathrm{BID}^{\mathrm{b}}$ & $\begin{array}{l}\text { Should be } \\
\text { administered } \\
\text { within } 60 \mathrm{~min} \\
\text { before main } \\
\text { meals }\end{array}$ & $\begin{array}{l}\text { Continue with the next scheduled } \\
\text { dose }\end{array}$ \\
\hline Liraglutide & Yes & $\begin{array}{l}0.6 \mathrm{mg} \text { OD } \\
\text { for at } \\
\text { least } \\
1 \text { week }\end{array}$ & $1.2-1.8 \mathrm{mg} \mathrm{OD}^{\mathrm{c}}$ & $\begin{array}{l}\text { At any time, } \\
\text { without regard } \\
\text { to meals }\end{array}$ & $\begin{array}{l}\leq 12 \mathrm{~h} \text { : administer the dose as soon } \\
\text { as possible } \\
>12 \mathrm{~h} \text { : skip the dose }\end{array}$ \\
\hline Lixisenatide & Yes & $\begin{array}{l}10 \text { mcg OD } \\
\text { for } \\
14 \text { days }\end{array}$ & $20 \mathrm{mcg}$ OD & $\begin{array}{l}\text { Should be } \\
\text { administered } \\
\text { within } 60 \mathrm{~min} \\
\text { before any meal }\end{array}$ & $\begin{array}{l}\text { Administer the dose within } 1 \mathrm{~h} \\
\text { before the next meal }\end{array}$ \\
\hline \multicolumn{6}{|l|}{ Once-weekly } \\
\hline Exenatide & No & $\begin{array}{l}\text { Not } \\
\text { applicable }\end{array}$ & $2 \mathrm{mg}$ once weekly & $\begin{array}{l}\text { At any time, } \\
\text { without regard } \\
\text { to meals }\end{array}$ & $\begin{array}{l}\text { Administer the next dose as soon as } \\
\text { practical. Only one injection } \\
\text { should be administered in a } 24-\mathrm{h} \\
\text { period }\end{array}$ \\
\hline Dulaglutide & $\mathrm{No}^{\mathrm{a}}$ & $\begin{array}{l}\text { Not } \\
\text { applicable }\end{array}$ & $\begin{array}{l}\text { Monotherapy: } \\
0.75 \mathrm{mg} \text { once } \\
\text { weekly } \\
\text { Add-on therapy: } \\
1.5 \mathrm{mg} \text { once weekly }\end{array}$ & $\begin{array}{l}\text { At any time, } \\
\text { without regard } \\
\text { to meals }\end{array}$ & $\begin{array}{l}\geq 3 \text { days until the next scheduled } \\
\text { dose: administer the dose as soon } \\
\text { as possible } \\
<3 \text { days: skip the dose, wait and } \\
\text { administer their next regularly } \\
\text { scheduled weekly dose }\end{array}$ \\
\hline Semaglutide & Yes & $\begin{array}{l}0.25 \mathrm{mg} \\
\text { once } \\
\text { weekly } \\
\text { for } \\
4 \text { weeks }\end{array}$ & $\begin{array}{l}0.5-1.0 \mathrm{mg} \text { once } \\
\text { weekly (dose } \\
\text { increase after } \\
4 \text { weeks if } \\
\text { required) }\end{array}$ & $\begin{array}{l}\text { At any time, } \\
\text { without regard } \\
\text { to meals }\end{array}$ & $\begin{array}{l}\geq 5 \text { days until the next scheduled } \\
\text { dose: administer the dose as soon } \\
\text { as possible } \\
<5 \text { days: skip the dose, wait and } \\
\text { administer their next regularly } \\
\text { scheduled weekly dose }\end{array}$ \\
\hline
\end{tabular}

Data were extracted from references [15-20, 30]

$B I D$ Twice a day, $O D$ once daily

a In elderly patients, a lower dose of $0.75 \mathrm{mg}$ once weekly can be considered

b Immediate-release exenatide should be initiated at $5 \mathrm{mcg}$ per dose administered BID for at least 1 month to improve tolerability; the dose can then be increased to $10 \mathrm{mcg}$ BID to further improve glycemic control

${ }^{c}$ Liraglutide should be initiated at a dose of $0.6 \mathrm{mg}$ daily to improve gastrointestinal tolerability; after at least 1 week, the dose should be increased to $1.2 \mathrm{mg}$ and a further increase to $1.8 \mathrm{mg}$ may be required to further improve glycemic control 
GLP-1 RAs differ in their requirements for the timing of administration with regard to meals. Immediate-release exenatide and lixisenatide should be administered before meals because they are associated with a greater delay in gastric emptying than once-weekly exenatide and dulaglutide [11]. Thus, immediate-release exenatide should be administered at any time within the 60-min period before the morning and evening meal (or two main meals of the day, approximately $\geq 6 \mathrm{~h}$ apart) [18]. Immediate-release exenatide should not be administered after a meal [18]. Once-daily lixisenatide also should be administered within $1 \mathrm{~h}$ before any meal of the day, preferably the same meal every day [19]. By contrast, prolonged-release exenatide [16], once-daily liraglutide and onceweekly dulaglutide and semaglutide $[15,17,20]$ can be administered without taking meals into account.

\section{INDICATIONS}

All GLP-1 RAs are indicated in combination with other glucose-lowering medication(s), including insulin, when these-together with diet and exercise-do not provide adequate glycemic control [15-20]. Liraglutide, dulaglutide and semaglutide are also indicated as monotherapy when there is inadequate glycemic control with diet/exercise and when metformin is considered to be inappropriate due to intolerance or contraindications $[15,17,20]$.

\section{ADMINISTRATION IN COMBINATION WITH ORAL ANTIDIABETIC DRUGS}

Recommendations for using GLP-1 RAs in combination with other antihyperglycemic agents vary across the agents. All GLP-1 RAs have been studied in combination with metformin, with or without sulfonylureas [21]. When a GLP-1 RA is administered in combination with a sulfonylurea, a reduction in the dose of the sulfonylurea should be considered, to reduce the risk of hypoglycemia [15-20]. GLP-1
RAs in combination with DPP-4 inhibitors do not provide additive glucose-lowering effects and therefore should be avoided [22].

Immediate- and prolonged-release exenatide, liraglutide, dulaglutide and semaglutide can be administered with pioglitazone-a thiazolidinedione-without the need to change the dose of pioglitazone [15-18, 20]. No information on dose adjustments of pioglitazone appears in the summary of product characteristics (SPC) of lixisenatide [19]. The use of the combination of GLP-1 RAs with SGLT2 inhibitors in patients with T2D has only been studied in randomized clinical trials with prolongedrelease exenatide [23, 24] and dulaglutide [25], and the results are summarized in their EU SPCs $[15,16]$.

\section{ADMINISTRATION IN COMBINATION WITH INSULIN}

In general, when a GLP-1 RA (e.g. immediaterelease exenatide, liraglutide, lixisenatide, dulaglutide or semaglutide) is administered in combination with basal insulin, it is recommended that a reduction in the dose of basal insulin should be considered to reduce the risk of hypoglycemia $[15,18-20]$. It has been reported that when prolonged-release exenatide was added to basal insulin, no initial dose adjustment of insulin was required [16]. There are no specific recommendations in the SPCs on how to reduce the dose of insulin. In some studies, the dose of insulin was reduced by $20 \%$ at randomization in all patients [26] or in those with an HbA1c of $<8 \%[27,28]$.

The addition of dulaglutide to a therapeutic regimen of prandial insulin lispro has also been evaluated in a randomized clinical trial in patients with T2D who did not achieve the target glycemic control with a basal-bolus regimen [29]. In this study, dulaglutide in combination with insulin lispro produced significantly greater reductions in HbA1c levels compared to insulin glargine combined with insulin lispro. However, there are limited data to support the general use of GLP-1 RA in combination with prandial insulin. 


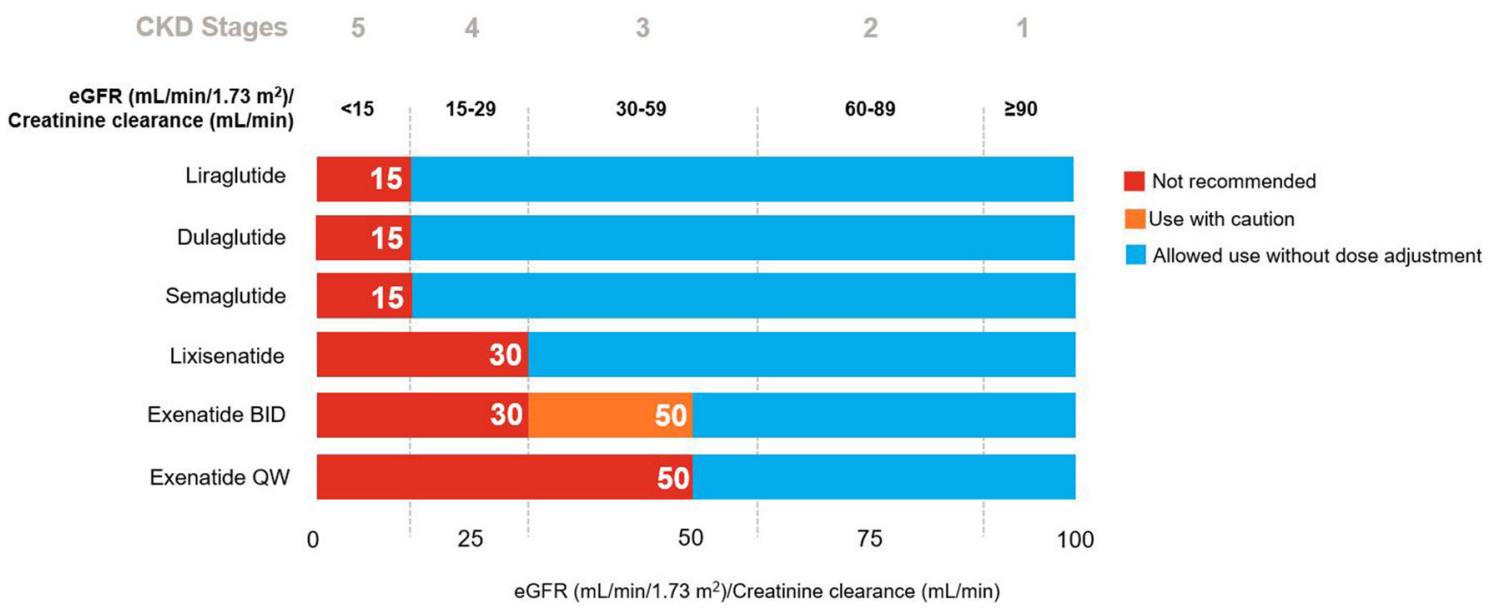

Fig. 1 Recommendations for the use of glucagon-like peptide-1 receptor agonists in patients with renal impairment. Based on the EU summary of product characteristic

\section{PRECAUTIONS FOR THE USE OF GLP-1 RAs IN SPECIAL POPULATIONS}

According to EU prescribing information, GLP-1 RAs should not be used in patients with type 1 diabetes mellitus or for the treatment of diabetic ketoacidosis.

Based on EU labels, there is no contraindication of the use of GLP-1 RAs in patients with personal or family history of medullary thyroid cancer or multiple endocrine neoplasia syndrome $[15-20,30]$. However, based on prescribing information issued by the U.S. Food and Drug Administration the use of dulaglutide, liraglutide, semaglutide and exenatide once weekly is contraindicated in these patients [31-34].

Gender and ethnicity have no clinically meaningful effect on the pharmacokinetics of GLP-1 RAs [15-20, 30]; therefore, dose adjustment based on these characteristics is not required. GLP-1 RAs do not require dose adjustments based on the body weight or the body mass index.

Most GLP-1 RAs do not require dose adjustment in elderly patients. However, a lower starting dose $(0.75 \mathrm{mg}$ once weekly) of dulaglutide can be considered in patients aged $\geq 75$ years [15]. Also, immediate-release of each agent [15-20]. BID twice daily, CKD Chronic Kidney Disease, $e G F R$ estimated glomerular filtration rate, $Q W$ once weekly

exenatide should be used with caution, and dose escalation from 5 to $10 \mathrm{mcg}$ should proceed conservatively in patients aged $>70$ years [16].

With the exception of exenatide, all GLP-1 RAs can be used without dose adjustments in patients with mild (estimated glomerular filtration rate [eGFR] $50-80 \mathrm{~mL} / \mathrm{min}$ ) or moderate (eGFR $30-50 \mathrm{~mL} / \mathrm{min}$ ) renal impairment [15-20] (Fig. 1). In patients with moderate renal impairment (creatinine clearance $30-50 \mathrm{~mL} /$ $\mathrm{min})$, immediate-release exenatide requires dose escalation [18], and exenatide once-weekly is not recommended [16]. Liraglutide [20], dulaglutide [15] and semaglutide [17] can be used in patients with severe renal impairment (eGFR $\geq 15$ to $<30 \mathrm{~mL} / \mathrm{min}$ ) without dose adjustment; however, the remaining GLP-1 RAs are not recommended in this population $[16,18,19]$. GLP-1 RAs are not recommended in patients with end-stage renal disease (eGFR $<15 \mathrm{~mL} / \mathrm{min}$ ) [15-20].

With the exception of liraglutide, all of the GLP-1 RAs can be used without dose adjustment in patients with hepatic impairment, regardless of severity [15-20]. The pharmacokinetics of liraglutide may be altered in patients with hepatic impairment due to the binding of liraglutide to serum albumin and concomitant hypoalbuminemia [20]. Systemic exposure to liraglutide has been found to be significantly 
lower (44\%) in patients with severe hepatic impairment (Child-Pugh score $>9$ ); therefore, this drug is not recommended in this population [20].

\section{SAFETY ISSUES, GENERAL WARNINGS AND PRECAUTIONS FOR THE USE OF GLP-1 RAs}

As a class, GLP-1 RAs are generally well tolerated [35]. The most common adverse events are nausea and vomiting, both of which are usually transient and of mild or moderate severity, and patients can develop tolerance to these adverse effects over time [35]. The frequency of nausea among patients ranges from $13 \%$ with dulaglutide $(0.75 \mathrm{mg})$, approximately $20 \%$ with liraglutide, prolonged-release exenatide, dulaglutide $(1.5 \mathrm{mg})$ and semaglutide, $26 \%$ with lixisenatide and $36 \%$ with one-daily exenatide. The rate of discontinuation due to gastrointestinal adverse events ranges from about 1\% with prolonged-release exenatide to $5 \%$ with semaglutide and once-daily exenatide [15-20].

Experience is limited on the use of the GLP-1 RAs in patients with severe gastrointestinal diseases, including gastroparesis. Therefore, these drugs are not recommended in these patients [15-20, 30].

Acute pancreatitis has been observed with the use of GLP-1 RAs [36]. According to the SPCs of all GLP-1 RAs, patients should be informed of the characteristic symptom of acute pancreatitis: persistent, severe abdominal pain $[15-20,30]$. If pancreatitis is suspected, these drugs should be discontinued; if acute pancreatitis is confirmed, they should not be restarted [15-20, 30]. Of note, two recent meta-analyses found no evidence that treatment with GLP-1 RAs increases the risk of acute pancreatitis or pancreatic cancer [37, 38]. Large, randomized CV outcome trials with GLP-1 RAs have not found any increased risk of pancreatitis or pancreatic cancers [37, 39-41].

Injection-site reactions have been described with GLP-1 RAs; however, it is difficult to compare the incidence between the GLP-1 RAs as data are limited. In one head-to-head comparison, injection-site nodules were less frequent with liraglutide than with once-weekly exenatide (1\% vs. $10 \%$ ) [42], while in another trial dulaglutide and liraglutide were associated with a similar frequency of injection-site reactions $(<1 \%)$ [43]. In one randomized, open-label trial, the frequency of injection-site reactions was reported in $1 \%$ of patients with dulaglutide at a dose of $0.75 \mathrm{mg}$ and semaglutide at a dose of $0.5 \mathrm{mg}$; at a higher dose of dulaglutide $(1.5 \mathrm{mg})$ and semaglutide $(1.0 \mathrm{mg})$, $3 \%$ and $2 \%$ of patients reported injection-site reactions, respectively [44]. Patients moving from twice-daily exenatide to once-weekly exenatide reported more injection-site reactions $(5.4 \%)$ than did patients on continuous onceweekly treatment $(0 \%)$ [45]. In another trial, injection-site reactions were more frequent with once-weekly exenatide than twice-daily exenatide (5.4\% vs. $2.4 \%$, respectively) [46].

There has been some concern-based on results from animal studies-regarding a potential association between the use of GLP-1 RAs and the occurrence of medullary thyroid tumors [47, 48]. However, a meta-analysis of 26 randomized controlled trials (RCTs) of onceweekly GLP-1 RAs showed that, compared to other antidiabetic drugs, once-weekly GLP-1 RAs did not increase the risk of any tumor [49].

Dehydration, sometimes leading to renal impairment and acute renal failure, has been reported in patients treated with GLP-1 RAs [47]. Therefore, patients treated with these drugs should be advised of the potential risk of dehydration [15-20], which usually occurs in association with gastrointestinal adverse effects but may occur without these adverse effects, and should take precautions to avoid fluid depletion [47]. In patients with diabetic retinopathy, an increased risk of developing diabetic retinopathy complications when treated with insulin and semaglutide has been observed. Therefore, caution should be exercised when prescribing semaglutide in combination with insulin to patients with diabetic retinopathy [17].

For a detailed description of other tolerability or safety issues of specific GLP-1 RAs, practicing physicians are referred to the corresponding SPCs [15-20]. 


\section{CLINICAL EFFICACY}

\section{Effects on Glycemic Control}

Overall, as shown by a meta-analysis of 57 randomized and non-randomized studies, GLP-1 RAs are effective in improving glycemic outcomes in patients with T2D, with an overall lower risk of hypoglycemia than insulin or sulfonylureas [50]. In a meta-analysis of 82 RCTs, the mean HbA1c decrease from baseline was approximately $1 \%$ versus placebo [51]. Another meta-analysis of 11 RCTs showed that prolonged-release exenatide and dulaglutide are associated with greater reductions in $\mathrm{HbA1c}$ level than basal insulin, whereas immediate-release exenatide and liraglutide were found not to differ in this regard from the comparator [52]. In a meta-analysis of 19 RCTs, GLP-1 RAs added to basal insulin therapy led to a greater reduction of HbA1c level and body weight than therapy with basal insulin with or without a rapid-acting insulin [53]. A meta-analysis of 13 RCTs reported that GLP-1 RAs were superior in terms of HbA1c level and weight reductions compared to DPP4 inhibitors, without increasing the incidence of hypoglycemia [54].

Predictors of response to GLP-1 RAs may differ across agents, while body weight and disease duration do not appear to affect the efficacy of these medications [55]. However, a higher HbA1c level at treatment initiation is associated with a greater efficacy of GLP-1 RAs [56].

\section{Other Effects}

From the clinical perspective, GLP-1 RAs represent a unique approach for the treatment of diabetes, with benefits extending beyond glucose control, including beneficial effects on body weight, blood pressure and beta-cell function $[57,58]$.

\section{Weight}

The effect of GLP-1 RAs on body weight is often included as a secondary outcome in many GLP-1 RA clinical trials [59]. The association between weight loss and GLP-1 RAs is well documented
$[59,60]$. In a meta-analysis of 51 randomized controlled and uncontrolled trials, weight loss with GLP-1 RAs ranged from -3.31 to $-1.22 \mathrm{~kg}$ compared to placebo, insulin or other oral antidiabetic drugs [60].

\section{Cardiovascular Events and Mortality}

Regulatory authorities recommend demonstrating CV safety for new antidiabetic agents $[61,62]$. Recent systematic reviews have demonstrated that, as a class, GLP-1 RAs are associated with a reduction in the risks of $\mathrm{CV}$ events $[59,63]$. For individual agents, however, this has only been demonstrated for liraglutide and semaglutide [39, 40, 49, 63]. Lixisenatide and prolonged-release exenatide have demonstrated a neutral effect on CV events [41, 64]. The impact of dulaglutide on CV events is currently being investigated in the REWIND RCT [65]. Further evidence to support the CV safety of GLP-1 RAs comes from a systematic review of 21 RCTs and four observational studies with GLP-1 RAs which showed no evidence of an increased risk of heart failure or hospitalization for heart failure with these medications [66].

Of the four GLP-1 RAs involved in these meta-analyses (lixisenatide, liraglutide, semaglutide and prolonged-release exenatide), only liraglutide and semaglutide have been shown in RCTs to reduce CV events (any major adverse CV events: CV death, non-fatal myocardial infarction or non-fatal stroke) in patients with T2D who are at high CV risk $[39,40]$. Liraglutide also significantly reduced all-cause death. Based on the American Diabetes Association (ADA) 2018 guidelines, consideration should be given to adding an agent with evidence of $\mathrm{CV}$ risk reduction to the therapeutic regimen of patients with diabetes and atherosclerotic $\mathrm{CV}$ disease [22].

\section{CHARACTERISTICS OF THE DIFFERENT GLP-1 RA DEVICES}

The complexity of dose regimens and patients' perceptions of medications, including perceived difficulty/ease of administration and fear of 
Table 3 Mode of administration and characteristics of glucagon-like peptide-1 receptor agonist pre-filled pen devices based on European Union summary of product characteristics

\begin{tabular}{|c|c|c|c|c|c|c|}
\hline Drug & $\begin{array}{l}\text { Reconstitution or } \\
\text { mixing required }\end{array}$ & $\begin{array}{l}\text { Automatic dose } \\
\text { administration }\end{array}$ & $\begin{array}{l}\text { Need to prime } \\
\text { device before use }\end{array}$ & $\begin{array}{l}\text { Needle } \\
\text { attachment } \\
\text { required }\end{array}$ & $\begin{array}{l}\text { Dose } \\
\text { selection } \\
\text { required }\end{array}$ & $\begin{array}{l}\text { Single } \\
\text { use }\end{array}$ \\
\hline \multicolumn{7}{|l|}{ Daily } \\
\hline Exenatide & No & No & Yes & $\begin{array}{c}\text { Yes. Needles are } \\
\text { not included }\end{array}$ & Yes & No \\
\hline Liraglutide & No & No & Yes & $\begin{array}{c}\text { Yes. Needles are } \\
\text { not included }\end{array}$ & Yes & No \\
\hline Lixisenatide & No & No & Yes & $\begin{array}{c}\text { Yes. Needles are } \\
\text { not included }\end{array}$ & Yes & No \\
\hline \multicolumn{7}{|l|}{ Once-weekly } \\
\hline Exenatide & Yes & No & No & $\begin{array}{l}\text { Yes. Needles are } \\
\text { included }\end{array}$ & No & Yes \\
\hline $\begin{array}{l}\text { Exenatide } \\
\text { BCISE (pre- } \\
\text { filled pen) }\end{array}$ & Yes & Yes & No & $\begin{array}{l}\text { No. Pre- } \\
\text { attached } \\
\text { hidden needle }\end{array}$ & No & Yes \\
\hline Dulaglutide & No & Yes & No & $\begin{array}{l}\text { No. Pre- } \\
\text { attached } \\
\text { hidden needle }\end{array}$ & No & Yes \\
\hline Semaglutide & No & No & Yes & $\begin{array}{l}\text { Yes. Needles are } \\
\text { included }\end{array}$ & Yes & No \\
\hline
\end{tabular}

Data are from references $[15-20,30]$

injections, are among the important factors affecting acceptance of the initiation of an injectable treatment and/or medication adherence in patients with T2D [67, 68]. Therefore, full knowledge of the characteristics and features of the different GLP-1 RA devices and their administration requirements (Table 3 ) could help physicians select the most appropriate agent for their patients.

All devices for daily formulations of GLP-1 RAs require needle attachment; however, needles are not provided by the manufacturer in the product's container for any daily GLP-1 RA. Devices for daily formulations and semaglutide require selection of the dose in the injection device and removal/disposal of the needle after each injection. Weekly formulations of dulaglutide and exenatide do not require selection of the dose and are single-use devices (Table 3) [15-20]. Prolonged-release exenatide requires reconstitution [16]. The pre-filled pen has two chambers containing exenatide powder and solvent. The powder in one chamber must be mixed with the solvent in the other chamber of the pre-filled pen. The solvent should be visually inspected before use and should only be used if it is clear and free of particulate matter. After suspension, the mixture should only be used if it is white to off-white and cloudy [16]. Prolonged-release exenatide has also recently become available as a single-use, fixed-dose, prefilled pen that features a pre-attached hidden needle and automatic dose administration that requires mixing of the medicine by shaking the device for $15 \mathrm{~s}$ before injection (Table 3) [16]. 
Dulaglutide includes a pre-attached hidden needle, and the dose is administered automatically by pressing a button (Table 3) [15]. The device is ready to use by the patient, since no dose selection, needle attachment, reconstitution or mixing procedure is required. The ease of use of dulaglutide was evaluated in an uncontrolled study conducted in 214 patients with T2D [69]. In this study, 99\% of patients considered the device to be easy or very easy to use [69]. In a study comparing patient perceptions of the injection devices used with liraglutide and dulaglutide, the dulaglutide device was associated with slightly higher scores for ease of use and convenience compared to the liraglutide device [70]. In a study conducted in 382 patients with T2D via an internet survey, patient preferences between liraglutide and twice-daily exenatide were evaluated using four attributes: efficacy as evaluated by $\mathrm{HbA1c}$; incidence of nausea; incidence of hypoglycemia; and dosing frequency [36]. In this study, $96 \%$ of respondents preferred the profile of liraglutide over that of exenatide. In an openlabel task and interview-based pilot study, the liraglutide and lixisenatide pen devices were associated with higher user satisfaction than the immediate-release exenatide pen [71].

\section{PLACE OF GLP-1 RAS IN THE TREATMENT OF T2D}

The GLP-1 RAs are well established as effective treatments for patients with T2D for whom lifestyle management (e.g. weight control, increased exercise) and antihyperglycemic monotherapy are insufficient to achieve glycemic targets. Clinical guidelines consider GLP-1 RAs as second-line treatment after metformin (dual therapy), as well as triple therapy and in combination with insulin [22]. Notably, the GLP-1 RAs can be considered to be an option when treatment intensification is required $[1,72,73]$, both as monotherapy (liraglutide, dulaglutide and semaglutide have been approved for use in this setting $[15,17,20])$ and combination therapy. However, cost-effectiveness is an important consideration as the high cost of GLP-1 RAs may act as a barrier for some patients [22].

Clinical evidence from many RCTs has shown that the GLP-1 RAs produce clinically meaningful improvements in glycemic control, including significant reductions in $\mathrm{HbA} 1 \mathrm{c}$ and fasting plasma glucose levels, both in patients with T2D of recent onset and in those with disease of long duration [74].

When used as components of dual or triple therapy regimens, GLP-1 RAs offer the double beneficial effect of a consistent glycemic control and a moderate weight loss with a low rate of hypoglycemia. A GLP-1 RA could be a preferred option when weight control [75-77] or avoidance of hypoglycemia is particularly important [76]. They also may be used as an alternative to basal insulin for certain patients, since they provide at least similar efficacy but without weight gain and, in some cases, a lower risk of hypoglycemia [4]. Most GLP-1 RAs do not require dose adjustment in elderly patients or in patients with mild to moderate renal impairment; therefore, they represent a useful treatment option in these patient populations.

In addition, GLP-1 RAs appear to have a favorable profile regarding CV risk factors. In fact, some agents are associated with a risk reduction of CV events [40] while others have a neutral effect in this regard [41]. Thus, GLP-1 RAs also offer potential advantages in patients at higher risk of CV events [76].

As a class, the GLP-1 RAs are generally well tolerated, with nausea and vomiting being the most common adverse events. It is important to inform patients initiating GLP-1 RA therapy that gastrointestinal related adverse effects may occur initially but that these effects are transient and are typically mild to moderate in nature [78]. If nausea is bothersome, the patient may be advised to take smaller meals, avoid spicy foods and make healthier food choices, since nausea is commonly reported after consuming a large or high-fat meal [78]. Also, returning the patient to a lower GLP-1 RA dose for $\geq 1$ week before repeating the incremental dosing steps can often prove successful in managing gastrointestinal adverse effects associated with this class of agents [78]. 


\section{CONCLUSIONS}

The GLP-1 RAs are a unique class of effective antihyperglycemic agents that enhance the actions of the naturally occurring peptide GLP-1. The mechanism of action of GLP-1 RAs is glucose dependent; as such, there is a low risk of hypoglycemia when not used in combination with sulfonylureas or insulin. Although, GLP-1 RAs share the same general mechanism of action, they differ in terms of their formulations, indications (monotherapy and/or combined therapy), injection devices, dosages, precautions and use in special patient populations. These agents also differ in terms of their effects on CV risk factors and gastrointestinal tolerability.

In accordance with clinical guidelines, GLP-1 RAs are not currently considered first-line therapy for T2D. They are, however, considered as second-line therapy in combination with oral antidiabetic drugs or insulin.

In this review, we have summarized and evaluated information relating to all of these issues, with a particular focus on practical considerations. This information has been compiled to help physicians select the most appropriate GLP-1 RA and to optimize the use of these agents, thereby improving the management of patients with T2D and enhancing health outcomes.

\section{ACKNOWLEDGEMENTS}

Funding. This work and associated article processing charges were supported by Eli Lilly and Company. All authors had full access to all of the data in this study and take complete responsibility for the integrity of the data and accuracy of the data analysis.

Medical Writing Assistance. The authors would like to thank Fernando Rico-Villademoros (COCIENTE S.L., Madrid, Spain) and Caroline Perry (Rx Communications, Mold, UK) for medical writing assistance with the preparation of this article. Support for this assistance was funded by Eli Lilly and Company.

Authorship. All named authors meet the International Committee of Medical Journal Editors (ICMJE) criteria for authorship for this article, take responsibility for the integrity of the work as a whole, and have given their approval for this version to be published.

Disclosures. Irene Romera is an employee of Eli Lilly and Company. Ana Cebrián-Cuenca has taken part in advisory boards for Sanofi and AstraZeneca Pharmaceuticals LP, and has acted as a speaker for Sanofi, Novo Nordisk, Boehringer Ingelheim, Bristol-Myers Squibb Company, Eli Lilly and AstraZeneca Pharmaceuticals LP. Fernando Álvarez Guisasola declares that he has no conflict of interest. Fernando Gomez Peralta has received a research grant from Sanofi, Novo Nordisk, Boehringer Ingelheim and Eli Lilly; has taken part in advisory boards for Sanofi, Novo Nordisk, and AstraZeneca Pharmaceuticals LP; and has acted as a speaker for Sanofi, Novo Nordisk, Boehringer Ingelheim, Bristol-Myers Squibb Company, Eli Lilly and AstraZeneca Pharmaceuticals LP. Jesús Reviriego is an employee and stock shareholder in Eli Lilly and Company.

Compliance with Ethics Guidelines. This article is based on previously conducted studies and does not contain any studies with human participants or animals performed by any of the authors.

Data Availability. Data sharing is not applicable to this article as no datasets were generated or analyzed during the current study.

Open Access. This article is distributed under the terms of the Creative Commons Attribution-NonCommercial 4.0 International License (http://creativecommons.org/licenses/ by-nc/4.0/), which permits any noncommercial use, distribution, and reproduction in any medium, provided you give appropriate credit to the original author(s) and the source, 
provide a link to the Creative Commons license, and indicate if changes were made.

\section{REFERENCES}

1. Inzucchi SE, Bergenstal RM, Buse JB, et al. Management of hyperglycemia in type 2 diabetes, 2015: a patient-centered approach: update to a position statement of the American Diabetes Association and the European Association for the Study of Diabetes. Diabetes Care. 2015;38(1):140-9.

2. Iglay K, Hannachi H, Joseph Howie P, et al. Prevalence and co-prevalence of comorbidities among patients with type 2 diabetes mellitus. Curr Med Res Opin. 2016;32(7):1243-52.

3. Meier JJ. GLP-1 receptor agonists for individualized treatment of type 2 diabetes mellitus. Nat Rev Endocrinol. 2012;8(12):728-42.

4. Lovshin JA. Glucagon-like peptide-1 receptor agonists: a class update for treating type 2 diabetes. Can J Diabetes. 2017;41(5):524-35.

5. Smilowitz NR, Donnino R, Schwartzbard A. Glucagon-like peptide-1 receptor agonists for diabetes mellitus: a role in cardiovascular disease. Circulation. 2014;129(22):2305-12.

6. Gupta V. Glucagon-like peptide-1 analogues: an overview. Indian $\mathrm{J}$ Endocrinol Metab. 2013;17(3):413-21.

7. Kalra S, Baruah MP, Sahay RK, Unnikrishnan AG, Uppal S, Adetunji O. Glucagon-like peptide-1 receptor agonists in the treatment of type 2 diabetes: past, present, and future. Indian J Endocrinol Metab. 2016;20(2):254-67.

8. Nikolaidis LA, Mankad S, Sokos GG, et al. Effects of glucagon-like peptide- 1 in patients with acute myocardial infarction and left ventricular dysfunction after successful reperfusion. Circulation. 2004;109(8):962-5.

9. Bose AK, Mocanu MM, Carr RD, Brand CL, Yellon DM. Glucagon-like peptide 1 can directly protect the heart against ischemia/reperfusion injury. Diabetes. $2005 ; 54(1): 146-51$.

10. GlaxoSmithKline. TANZEUM (albiglutide) discontinuation-Q\&A. 2017. https://www.tanzeum.com/ pdfs/consumer-faq.pdf. Accessed 21 Jun 2018.

11. Madsbad S. Review of head-to-head comparisons of glucagon-like peptide-1 receptor agonists. Diabetes Obes Metab. 2016;18(4):317-32.
12. Dalsgaard NB, Vilsboll T, Knop FK. Effects of glucagon-like peptide-1 receptor agonists on cardiovascular risk factors: a narrative review of head-tohead comparisons. Diabetes Obes Metab. 2018;20(3):508-19.

13. Bettge K, Kahle M, Abd El Aziz MS, Meier JJ, Nauck MA. Occurrence of nausea, vomiting and diarrhoea reported as adverse events in clinical trials studying glucagon-like peptide-1 receptor agonists: a systematic analysis of published clinical trials. Diabetes Obes Metab. 2017;19(3):336-47.

14. Matza LS, Curtis SE, Jordan JB, Adetunji O, Martin SA, Boye KS. Physician perceptions of GLP-1 receptor agonists in the UK. Curr Med Res Opin. 2016;32(5):857-64.

15. European Medicines Agency. Trulicity; summary of product characteristics. 2018. http://www.ema. europa.eu/docs/en_GB/document_library/EPAR_Product_Information/human/002825/WC5001794 70.pdf. Accessed 29 May 2018.

16. European Medicines Agency. Bydureon; summary of product characteristics. 2018. http://ec.europa. $\mathrm{eu} /$ health/documents/community-register/2018/20 180827141897/anx_141897_en.pdf. Accessed 03 Sept 2018.

17. European Medicines Agency. Ozempic; summary of product characteristics. 2018. http://www.ema. europa.eu/docs/en_GB/document_library/EPAR_Product Information/human/004174/WC500244 63.pdf. Accessed 03 Sept 2018.

18. European Medicines Agency. Byetta; summary of product characteristics. 2018. http://www.ema. europa.eu/docs/en_GB/document_library/EPAR Product_Information/human/000698/WC5000518 45.pdf. Accessed 29 May 2018.

19. European Medicines Agency. Lyxumia; summary of product characteristics. 2017. http://www.ema. europa.eu/docs/en_GB/document_library/EPAR_-Product_Information/human/002445/WC5001404 01.pdf. Accessed 29 May 2018.

20. European Medicines Agency. Victoza; summary of product characteristics. 2018. http://www.ema. europa.eu/docs/en_GB/document_library/EPAR_-_ Product_Information/human/001026/WC5000500 17.pdf. Accessed 29 May 2018.

21. St Onge E, Miller S, Clements E, Celauro L, Barnes $\mathrm{K}$. The role of glucagon-like peptide-1 receptor agonists in the treatment of type 2 diabetes. J Transl Int Med. 2017;5(2):79-89.

22. American Diabetes Association. 8. Pharmacologic approaches to glycemic treatment: standards of 
medical care in diabetes-2018. Diabetes Care. 2018;41[Suppl 1]:S73-85.

23. Jabbour SA, Frias JP, Guja C, Hardy E, Ahmed A, Ohman P. Effects of exenatide once weekly plus dapagliflozin, exenatide once weekly, or dapagliflozin, added to metformin monotherapy, on body weight, systolic blood pressure, and triglycerides in patients with type 2 diabetes in the DURATION-8 study. Diabetes Obes Metab. 2018;20:1515-9.

24. Frias JP, Guja C, Hardy E, et al. Exenatide once weekly plus dapagliflozin once daily versus exenatide or dapagliflozin alone in patients with type 2 diabetes inadequately controlled with metformin monotherapy (DURATION-8): a 28 week, multicentre, double-blind, phase 3 , randomised controlled trial. Lancet Diabetes Endocrinol. 2016;4(12):1004-16.

25. Ludvik B, Frias JP, Tinahones FJ, et al. Dulaglutide as add-on therapy to SGLT2 inhibitors in patients with inadequately controlled type 2 diabetes (AWARD-10): a 24-week, randomised, double-blind, placebo-controlled trial. Lancet Diabetes Endocrinol. 2018;6:370-81.

26. Mathieu C, Rodbard HW, Cariou B, et al. A comparison of adding liraglutide versus a single daily dose of insulin aspart to insulin degludec in subjects with type 2 diabetes (BEGIN: VICTOZA ADDON). Diabetes Obes Metab. 2014;16(7):636-44.

27. Pozzilli P, Norwood P, Jodar E, et al. Placebo-controlled, randomized trial of the addition of onceweekly glucagon-like peptide- 1 receptor agonist dulaglutide to titrated daily insulin glargine in patients with type 2 diabetes (AWARD-9). Diabetes Obes Metab. 2017;19(7):1024-31.

28. Buse JB, Bergenstal RM, Glass LC, et al. Use of twicedaily exenatide in Basal insulin-treated patients with type 2 diabetes: a randomized, controlled trial. Ann Intern Med. 2011;154(2):103-12.

29. Blonde L, Jendle J, Gross J, et al. Once-weekly dulaglutide versus bedtime insulin glargine, both in combination with prandial insulin lispro, in patients with type 2 diabetes (AWARD-4): a randomised, open-label, phase 3, non-inferiority study. Lancet. 2015;385(9982):2057-66.

30. European Medicines Agency. Eperzan. Summary of product characteristics. 2017. http://www.ema. europa.eu/docs/en_GB/document_library/EPAR_-_ Product_Information/human/002735/WC5001651 17.pdf. Accessed 29 May 2018.

31. Food and Drug Administration. Trulicity; highlights of prescribing information. 2014. https:// www.accessdata.fda.gov/drugsatfda_docs/label/2017/ 125469s011s013lbl.pdf. Accessed 30 Aug 2018.
32. Food and Drug Administration. Victoza; highlights of prescribing information. 2010. https://www. accessdata.fda.gov/drugsatfda_docs/label/2017/022 341s027lbl.pdf. Accessed 30 Aug 2018.

33. Food and Drug Administration. Bydureon; highlights of prescribing information. 2012. https:// www.accessdata.fda.gov/drugsatfda_docs/label/2012/ 022200s000lbl.pdf. Accessed 30 Aug 2018.

34. Food and Drug Administration. Ozempic; highlights of prescribing information. 2017. https:// www.accessdata.fda.gov/drugsatfda_docs/label/2017/ 209637lbl.pdf. Accessed 03 Sept 2018.

35. Raccah D. Safety and tolerability of glucagon-like peptide-1 receptor agonists: unresolved and emerging issues. Expert Opin Drug Saf. 2017;16(2):227-36.

36. Polster M, Zanutto E, McDonald S, Conner C, Hammer M. A comparison of preferences for two GLP-1 products-liraglutide and exenatide-for the treatment of type 2 diabetes. J Med Econ. 2010;13(4):655-61.

37. Monami M, Nreu B, Scatena A, et al. Safety issues with glucagon-like peptide-1 receptor agonists (pancreatitis, pancreatic cancer and cholelithiasis): data from randomized controlled trials. Diabetes Obes Metab. 2017;19(9):1233-41.

38. Storgaard H, Cold F, Gluud LL, Vilsboll T, Knop FK. Glucagon-like peptide-1 receptor agonists and risk of acute pancreatitis in patients with type 2 diabetes. Diabetes Obes Metab. 2017;19(6):906-8.

39. Marso SP, Bain SC, Consoli A, et al. Semaglutide and cardiovascular outcomes in patients with type 2 diabetes. N Engl J Med. 2016;375(19):1834-44.

40. Marso SP, Daniels GH, Brown-Frandsen $\mathrm{K}$, et al. Liraglutide and cardiovascular outcomes in type 2 diabetes. N Engl J Med. 2016;375(4):311-22.

41. Holman RR, Bethel MA, Mentz RJ, et al. Effects of once-weekly exenatide on cardiovascular outcomes in type 2 diabetes. $\mathrm{N}$ Engl $\mathrm{J}$ Med. 2017;377(13):1228-39.

42. Buse JB, Nauck M, Forst $T$, et al. Exenatide once weekly versus liraglutide once daily in patients with type 2 diabetes (DURATION-6): a randomised, open-label study. Lancet. 2013;381(9861):117-24.

43. Dungan KM, Povedano ST, Forst T, et al. Onceweekly dulaglutide versus once-daily liraglutide in metformin-treated patients with type 2 diabetes (AWARD-6): a randomised, open-label, phase 3, non-inferiority trial. Lancet. 2014;384(9951): 1349-57. 
44. Pratley RE, Aroda VR, Lingvay I, et al. Semaglutide versus dulaglutide once weekly in patients with type 2 diabetes (SUSTAIN 7): a randomised, openlabel, phase $3 \mathrm{~b}$ trial. Lancet Diabetes Endocrinol. 2018;6(4):275-86.

45. Buse JB, Drucker DJ, Taylor KL, et al. DURATION-1: exenatide once weekly produces sustained glycemic control and weight loss over 52 weeks. Diabetes Care. 2010;33(6):1255-61.

46. Blevins T, Pullman J, Malloy J, et al. DURATION-5: exenatide once weekly resulted in greater improvements in glycemic control compared with exenatide twice daily in patients with type 2 diabetes. J Clin Endocrinol Metab. 2011;96(5):1301-10.

47. Filippatos TD, Panagiotopoulou TV, Elisaf MS. Adverse effects of GLP-1 receptor agonists. Rev Diabet Stud. 2014;11(3-4):202-30.

48. Thrasher J. Pharmacologic management of type 2 diabetes mellitus: available therapies. Am J Med. 2017;130[Suppl 6]:S4-17.

49. Bethel MA, Patel RA, Merrill P, et al. Cardiovascular outcomes with glucagon-like peptide-1 receptor agonists in patients with type 2 diabetes: a metaanalysis. Lancet Diabetes Endocrinol. 2018;6(2):105-13.

50. Levin PA, Nguyen H, Wittbrodt ET, Kim SC. Glucagon-like peptide-1 receptor agonists: a systematic review of comparative effectiveness research. Diabetes Metab Syndr Obes. 2017;10:123-39.

51. Waldrop G, Zhong J, Peters M, et al. Incretin-based therapy in type 2 diabetes: an evidence based systematic review and meta-analysis. J Diabetes Complications. 2018;32(1):113-22.

52. Singh S, Wright EE Jr, Kwan AY, et al. Glucagon-like peptide-1 receptor agonists compared with basal insulins for the treatment of type 2 diabetes mellitus: a systematic review and meta-analysis. Diabetes Obes Metab. 2017;19(2):228-38.

53. Wysham CH, Lin J, Kuritzky L. Safety and efficacy of a glucagon-like peptide- 1 receptor agonist added to basal insulin therapy versus basal insulin with or without a rapid-acting insulin in patients with type 2 diabetes: results of a meta-analysis. Postgrad Med. 2017;129(4):436-45.

54. Tran S, Retnakaran R, Zinman B, Kramer CK. Efficacy of glucagon-like peptide-1 receptor agonists compared to dipeptidyl peptidase- 4 inhibitors for the management of type 2 diabetes: a meta-analysis of randomized clinical trials. Diabetes Obes Metab. 2018;20[Suppl 1]:S68-76.
55. Monami M, Dicembrini I, Nreu B, Andreozzi F, Sesti G, Mannucci E. Predictors of response to glucagonlike peptide-1 receptor agonists: a meta-analysis and systematic review of randomized controlled trials. Acta Diabetol. 2017;54(12):1101-14.

56. Bihan H, Ng WL, Magliano DJ, Shaw JE. Predictors of efficacy of GLP-1 agonists and DPP-4 inhibitors: a systematic review. Diabetes Res Clin Pract. 2016;121:27-34.

57. Prasad-Reddy L, Isaacs D. A clinical review of GLP-1 receptor agonists: efficacy and safety in diabetes and beyond. Drugs Context. 2015;4:212283.

58. Nauck MA, Meier JJ, Cavender MA. Abd El Aziz M, Drucker DJ. Cardiovascular actions and clinical outcomes with glucagon-like peptide-1 receptor agonists and dipeptidyl peptidase- 4 inhibitors. Circulation. 2017;136(9):849-70.

59. Sfairopoulos D, Liatis S, Tigas S, Liberopoulos E. Clinical pharmacology of glucagon-like peptide-1 receptor agonists. Hormones (Athens). 2018;17(3):333-50.

60. Sun F, Chai S, Li L, et al. Effects of glucagon-like peptide-1 receptor agonists on weight loss in patients with type 2 diabetes: a systematic review and network meta-analysis. J Diabetes Res. 2015;2015:157201.

61. Smith RJ, Goldfine AB, Hiatt WR. Evaluating the cardiovascular safety of new medications for type 2 diabetes: Time to reassess? Diabetes Care. 2016;39(5):738-42.

62. European Medicines Agency. Assessment report for GLP-1 based therapies. 2013. https://www.ema. europa.eu/documents/report/assessment-reportarticle-53-procedure-glp-1-based-therapies_en.pdf. Accessed 23 Oct 2018.

63. Jia X, Alam M, Ye Y, Bajaj M, Birnbaum Y. GLP-1 receptor agonists and cardiovascular disease: a meta-analysis of recent cardiac outcome trials. Cardiovasc Drugs Ther. 2018;32(1):65-72.

64. Pfeffer MA, Claggett B, Diaz R, et al. Lixisenatide in patients with type 2 diabetes and acute coronary syndrome. N Engl J Med. 2015;373(23):2247-57.

65. ClinicalTrials.gov. Researching Cardiovascular Events With a Weekly Incretin in Diabetes (REWIND). 2018. https://clinicaltrials.gov/ct2/ show/NCT01394952. Accessed 10 Sept 2018.

66. Li L, Li S, Liu J, et al. Glucagon-like peptide-1 receptor agonists and heart failure in type 2 diabetes: systematic review and meta-analysis of randomized and observational studies. BMC Cardiovasc Disord. 2016;16:91. 
67. Rex J, Jensen KH, Lawton SA. A review of 20 years' experience with the NovoPen family of insulin injection devices. Clin Drug Investig. 2006;26(7):367-401.

68. Garcia-Perez LE, Alvarez M, Dilla T, Gil-Guillen V, Orozco-Beltran D. Adherence to therapies in patients with type 2 diabetes. Diabetes Ther. 2013;4(2):175-94.

69. Matfin G, Brunt KV, Zimmermann AG, Threlkeld R, Ignaut DA. Safe and effective use of the once weekly dulaglutide single-dose pen in injection-naïve patients with type 2 diabetes. J Diabetes Sci Technol. 2015;9(5):1071-9.

70. Matza LS, Boye KS, Currie BM, et al. Patient perceptions of injection devices used with dulaglutide and liraglutide for treatment of type 2 diabetes. Curr Med Res Opin. 2018;34:1457-64.

71. Stauder U, Enginee D, Elton H, Penfornis A, Edelman S. Comparative assessment of lixisenatide, exenatide, and liraglutide pen devices: a pilot userbased study. J Diabetes Sci Technol. 2014;8(1):123-31.

72. Garber AJ, Abrahamson MJ, Barzilay JI, et al. Consensus statement by the American Association of Clinical Endocrinologists and American College of Endocrinology on the comprehensive type 2 diabetes management algorithm-2017 executive summary. Endocr Pract. 2017;23(2):207-38.
73. Garber AJ, Abrahamson MJ, Barzilay JI, et al. Consensus statement by the American Association of Clinical Endocrinologists and American College of Endocrinology on the comprehensive type 2 diabetes management algorithm-2018 executive summary. Endocr Pract. 2018;24(1):91-120.

74. Gallwitz B, Dagogo-Jack S, Thieu V, et al. Effect of once-weekly dulaglutide on glycated haemoglobin (HbA1c) and fasting blood glucose in patient subpopulations by gender, duration of diabetes and baseline HbA1c. Diabetes Obes Metab. 2018;20(2):409-18.

75. Artola Menéndez S. Actualización del algoritmo de hiperglucemia 2017. Diabetes Práctica. 2017;08(02):57-60.

76. Kim HJ, Park SO, Ko SH, et al. Glucagon-like peptide- 1 receptor agonists for the treatment of type 2 diabetes mellitus: a position statement of the Korean Diabetes Association. Diabetes Metab J. 2017;41(6):423-9.

77. American Diabetes Association. 7. Obesity management for the treatment of type 2 diabetes: standards of medical care in diabetes-2018. Diabetes Care. 2018;41[Suppl 1]:S65-72.

78. Reid TS. Practical use of glucagon-like peptide-1 receptor agonist therapy in primary care. Clin Diabetes. 2013;31(4):148-57. 